\title{
The Effect of Achievement Motivation and Self-Regulated Learning on Student Learning Behavior in the Time of Online Learning in Indonesia
}

\author{
Juliana Hindradjat' ${ }^{1}$, Imam Hambali² ${ }^{2}$, Adi Atmoko² ${ }^{2}$, P. H. Livana ${ }^{3}$ (D) \\ ${ }^{1}$ Department of Christian Education, Sekolah Tinggi Teologi Kharisma, Bandung, Indonesia; ${ }^{2}$ Department of Guidance and \\ Councelling, Faculty of Education, Universitas Negeri Malang, Java, Indonesia; ${ }^{3}$ Department of Nursing and Professionals \\ Undergraduate Study Programs, Sekolah Tinggi IImu Kesehatan Kendal, Jawa Tengah, Indonesia
}

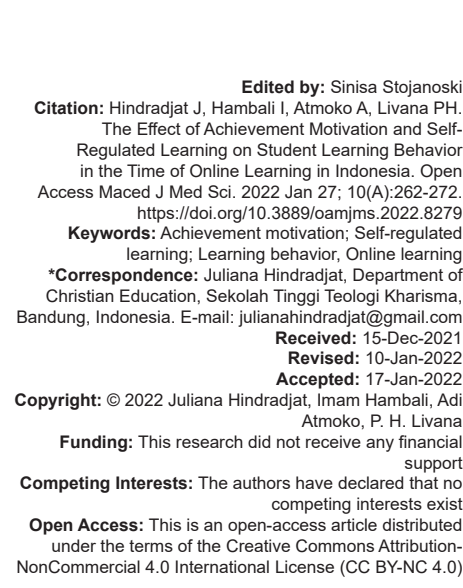

\begin{abstract}
BACKGROUND: Self-regulated learning (SRL) and achievement motivation are important variables in students learning behavior.
\end{abstract}

AIM: The purpose of this study was to examine the effect of achievement motivation and SRL on the learning behavior of junior high school students in Indonesia during the online learning period.

METHODS: The research uses a quantitative approach with a causal associative research design. The research population is junior high school students in grades VII, VIII, and IX from various regions in Indonesia during the online learning period. Research respondents total 2,880 students, who were selected through random sampling technique. Respondent data were collected using a set of questionnaires in the form of a validated achievement motivation scale, SRL, and learning behavior, and processed and analyzed using the path-analysis method.

RESULTS: The results of statistical processing show that the correlation coefficient between Achievement Motivation and SRL is 0.432 with a significant relationship and is included in the category of a fairly strong relationship. The correlation coefficient between Achievement Motivation and Learning Behavior is 0.632 with a significant relationship and is included in the category of a strong relationship. The correlation coefficient between SRL and Learning Behavior is 0.675 with a significant relationship and is included in the category of a strong relationship. Based on the Path Analysis Calculation Result Table, the path coefficient value for Achievement Motivation is 0.418 with a positive relationship direction. Simultaneous test results obtained the conclusion that there is an influence between Achievement Motivation and SRL variables on Learning Behavior of $59.8 \%$, while the remaining $40.2 \%$ is the influence of other variables not involved in this study. The direct influence of Achievement Motivation on Learning Behavior is $17.5 \%$ and the indirect effect through SRL is $8.9 \%$, so that if added up, the total effect is $26.4 \%$. Then, the direct influence of SRL on Learning Behavior is $24.4 \%$ and the indirect effect through Achievement Motivation is $8.9 \%$ so that if added up, the total effect is $33.4 \%$.

CONCLUSION: There is a significant effect between achievement motivation and SRL on student learning behavior simultaneously; there is a significant influence between achievement motivations on student learning behavior partially. There is a significant influence between SRL on Student Learning Behavior partially.

\section{Introduction}

Corona Virus Disease 2019 (COVID-19) was first discovered in the city of Wuhan, China at the end of December 2019. This virus spreads very quickly and in a relatively short time has spread to almost all countries, including Indonesia, so it needs to be handled directly by $\mathrm{WHO}$ and then in a short time. March 11, 2020 was declared a global pandemic outbreak [1], [2], [3], [4], [5], [6]. To stem the spread of the COVID-19 virus, several countries have set policies to enforce a lockdown, otherwise known as the Large-Scale Social Restriction (PSBB) policy in Indonesia. During the PSBB period, all activities carried out outside the home must be limited until the pandemic is considered to have subsided, including learning activities. During the COVID-19 pandemic, the Indonesian government determined the implementation of online learning from home for health reasons as an effort to prevent the transmission of the COVID-19 disease, which total more than 4 million cases by the end of 2021, according to the policy of the Minister of Education and Culture of the Republic of Indonesia regarding the Circular Letter Number 4 of 2020, concerning the Implementation of Education Policies in the Emergency Period for the Spread of COVID19. The world of education around the world, including Indonesia is facing unprecedented challenges in the provision of online education services [7].

Strict restrictions on learning activities ultimately have an impact on changes that require adjustments in various aspects of their implementation. Teachers are not allowed to teach students face-to-face, especially 
in areas where the number of COVID-19 cases is quite high, where the learning process must be carried out using various internet-based applications. The teacher's job is to ensure that students continue to study even from home, in the most effective way possible. Teachers are required to be able to design effective online learning designs, using devices such as mobile phones, laptops, tablets, and appropriate online media according to the material to be delivered.

The online learning system from home during the PSBB period also affects students. Apart from teachers, many students are also unprepared with online learning methods. Personally, students themselves are also required to make various adjustments, considering that the learning period is carried out from home. Personal characteristics and student learning also experience various changes during the online learning period where student learning activity and motivation in Indonesia decreases due to factors that do not support the student learning process during the pandemic, including technological capabilities, internet network access connections, learning media that used, and student capacity for online learning. [8], [9], [10], [11]. However, other studies have shown that during the online learning period; student motivation is very good and students are able to increase motivation and interest, learn independence, and have the courage to express ideas and questions [12]. In addition to the problem of mastering technology, successful online learning facilities and infrastructure depend on the ability of students to control the self-regulated learning (SRL) process. SRL is "an active and constructive process in which learners set goals for learning and then seek to monitor, regulate, and control their cognition, motivation, and behavior, guided and constrained by contextual goals and features in the environment" [13].

However, the implementation, student learning achievement remains a reference to the level of student achievement where this is influenced by various variables, including SRL, achievement motivation, and student learning behavior. Research shows that students' academic success is contributed by several academic, psychosocial, and behavioral factors [14], [15]. Furthermore, Casillas et al. (14) also found that, although previous grades and standardized attainment were the most predictive of eighth graders' middle school performance, psychosocial factors (e.g., self-regulation, motivation, social control) and behavior increased predictive power [16]. Moreover, one of the tasks of school counsellors is to identify and intervene in students who have risky or destructive behaviors that have a negative impact, including experiencing drop-outs and failure to graduate from school [17]. In contrast to Western culture, academic achievement in Eastern culture is not only related to individual success in seeking knowledge but is also important to bring prosperity, power, popularity, and family honour [18].

\section{Achievement Motivation, SRL and Learning Behavior}

Motivation describes the reasons for choosing, willingness to persist and how much effort people invest in a particular activity [19]. Motivation can function as a precursor, mediator, and outcome of SRL, so that it ultimately plays an important role in regulating students' learning efforts. Literature shows that motivational beliefs interact with cognitive, behavioral, and contextual variables in the process of self-regulation [20], [21].

There are two factors that influence student achievement motivation during online learning, namely internal and external. Internal factors consist of encouragement to increase knowledge, independent learning, sense of responsibility, encouragement to improve academic achievement, and the ability to manage oneself as well as external. While external factors that influence student achievement motivation are the role of parents and teachers, the presence of the family as role models, contributions from outside the school in increasing knowledge [22].

Many factors influence student learning behavior. In some early research, self-efficacy and goal orientation have been shown to be related to student learning behavior [23], [24], [25], which can be conceptualized in terms of learning behaviors that depth and surface. Deep learning behavior is associated with a willingness to understand and engage in meaningful learning and use appropriate strategies to acquire knowledge. Like self-efficacy, learning behavior affects performance outcomes [26]

The definition of inclusion of SRL was generated through a symposium held in 1986 where experts agreed to describe SRL as the extent to which students metacognitively, motivated, and behaviorally play an active role in their own learning process [27], and then a number of instruments were developed to assess SRL as a metacognitive, motivational and behavioral construct, including the Learning and Study Strategies Inventory in 1987, the Motivated Strategies for Learning Questionnaire in 1993, Self-Regulated Learning Interview Scale in 1986 Measures of selfregulation strategies also predict students' academic scores and their teachers' assessment of their proactive efforts while learning in the classroom [28]. Furthermore, the definition focuses on the proactive use of studentspecific processes or responses to improve academic achievement [29]

According to Zimmerman [30] self-regulation is a self-directed process in which learners convert their mental abilities into academic skills (p. 65), selfregulation is a metacognitive process that requires students to explore their own thought processes so as to evaluate the results of actions and plan alternative pathways. To success. Successful students organize 
work, set goals, seek help when needed, use effective work strategies, and manage their time [28], [30]. These students act as agents, proactively involved in their own development and their present and future academic authors [30], [31].

Students are declared to have SRL if they intentionally activate, maintain, and adjust their cognition, influence, and behavior to achieve their learning goals SRL is a dynamic and cyclical process in which students need to apply various strategies to help students actively controlling mental states, beliefs, observable behaviors, and learning environments [32]. $\mathrm{SRL}$ includes several dimensions to regulate cognition, metacognition, social behavior, and motivation in different learning contexts [32], [33], [34]. Motivational support is needed in the use of SRL strategies to help students initiate, sustain, and enhance learning efforts [20], [21].

Regarding gender differences, research conducted by Zimmerman and Pons (1990) revealed that female students demonstrated more goal-setting and strategic planning than male students and made self-recording and self-monitoring more often than male students. In addition, the ability to develop an environment for optimal learning of female students is also higher than that of male students [28]. Furthermore, Usher and Pajares [31] also stated that self-efficacy for self-study scores was positively correlated with the selfefficacy index, self-concept, task goal orientation, and academic achievement and negatively correlated with the academic anxiety index. Further assessment of students' self-efficacy beliefs for independent learning can provide important insights into students' academic motivation, behavior, and future choices.

Motivation is a multifaceted construct that includes the traits and conditions that direct and energize learning behavior [19], for example, planning, goal setting, monitoring and evaluation. Some researchers concluded that highly motivated students outperformed low motivated students in utilizing cognitive and metacognitive strategies, paying attention, and exerting effort in their learning process [20], [21]. As an important component of SRL, self-efficacy plays a central role in the exercise of personal agency with a strong impact on thinking, influence, motivation, and action [23]. Good student learning behavior, among others marked by perseverance and high academic performance, is influenced by self-efficacy which is one of the important components of SRL [21], [35].

A review based on empirical evidence provides merit for an exploratory approach to examine affective differences (motivation and self-efficacy) in SRL strategies. However, there is a paucity of research investigating how the different components of motivational beliefs and self-efficacy affect learners' regulation of cognition, metacognition, motivation, and behavior. Teng's [21] research was designed to fill this gap by investigating how motivational beliefs and self-efficacy impact multidimensional SRL strategies.

Value-expectancy theory holds the belief that 'humans are innate active learners with an innate curiosity and drive to get to know their environment and face challenges [19], within this theoretical framework, the expectancy component refers to students' beliefs about their ability to complete tasks [36]. Control beliefs are another important component, referring to the learner's perception that outcomes depend on one's own efforts, rather than external factors such as teachers or luck [37]. Belief control is closely related to metacognitive strategies in educational contexts [36], [37].

The grades component focuses on the reasons students engage in academic assignments [36]. Other researchers [38], [39] further report that students' intrinsic value is strongly associated with cognitive and metacognitive strategies both in general education and in second/foreign language environments [21].

Another critical and well-researched dimension of goal-oriented motivation is usually divided into intrinsic goal orientation and extrinsic goal orientation [13]. Intrinsic goal orientation refers to 'the state in which learners are willing to learn the target subject matter or skills for different reasons such as interest in content, desire to improve knowledge or skills, or desire to feel achievement, challenge, curiosity, and mastery [36]. Extrinsic goal orientation refers to a state in which 'learners are encouraged to learn based on external rewards such as obtaining a prize, getting good grades, or avoiding situations that might threaten their ego. Previous studies have shown that intrinsic goal orientation is closely related to the use of SRL strategies, thereby contributing to academic achievement in various educational contexts [40], [41]. Many studies in educational psychology underscore the importance of motivational beliefs in the self-regulation process, how different motivational components work on SRL strategies [21]. In the self-regulated process, students need to apply various strategies to help them intentionally activate, maintain, and adjust cognition, influence, and behavior to achieve learning goals [42].

Students' motivational beliefs, that is, developed mindset, self-efficacy, and intrinsic value predict selfregulation strategies (i.e., monitoring, regulatory effort, and goal setting and planning) in different ways [43]. In a subsequent study, they investigated the relationship between motivational beliefs, SRL strategies, and English writing competence. Results from structural equation modelling revealed that interest (reflecting the intrinsic value of motivational beliefs) had a positive predictive effect on several types of SRL strategies (i.e., self-starting, acting on feedback, and revising). Both studies conducted by Bai and Wang [38] show a relationship between motivational beliefs and the use of $\mathrm{SRL}$ strategies, such as cognitive strategies and metacognitive strategies [21]. 
The goal of motivational regulation strategies is 'to generate and enhance students' motivation, as well as to maintain sustained motivated behavior and protect it from distractions and/or resolve action tendencies [19]. Different aspects of motivational regulation strategies (e.g., emotional control, increased interest, mastery of self-talk, self-talk performance, and self-consequencing) were reported to be positively related to persistence, effort, goal orientation, cognitive and metacognitive strategies, and academic achievement [33], [44].

The ability to manage feelings, attitudes, and behaviors that affect a person's openness and implementation of learning activities is known as selfregulation [45]. Self-regulation according to Zimmerman and Schunk [46] is the ability to motivate, direct, and reflect on thoughts and behavior. Furthermore, Zimmerman [30] states that self-regulation involves personal responsibility and control over one's own learning. Self-regulated adolescents tend to monitor their own learning processes, and participate in metacognitive decision making [47], [48]. Researchers have found that self-regulation is a strong predictor of successful student academic achievement [47], [48], [49]. Combined with socioeconomic status, decision-making competencies that exhibit self-regulation are often is the most consistent predictor of GPA for adolescent students [16], [48].

SRL involves personally initiated metacognitive, motivational, and behavioral processes to acquire knowledge and skills, such as goal setting, planning, learning strategies, self-reinforcement, self-recording, and self-instruction. The SRL perspective shifts the focus of educational analysis from students' learning abilities and the instructional environment as fixed entities to student-initiated processes to improve their learning methods and environments. The main problem in defining learning as self-regulation is not social isolation but whether the learner displays personal initiative, persistence, and adaptive skills in an attempt to achieve it [50].

Research related to SRL has been widely carried out because of its ability to describe, explain and predict student behavior and learning outcomes. Various studies have proven that student achievement goals are significantly related to $S R L$ features, especially aspects of SRL that reflect epistemic motivation and beliefs [51]. $\mathrm{SRL}$ plays a more significant role in online learning environments than in traditional classroom settings. Online contexts tend to demand greater autonomous thinking and action from students due to limited external support [52]. The results of the literature study concluded that SRL plays a positive role in online learning in various educational contexts. In addition, there are several SRL strategies that have consistently been shown to have a strong influence on achievement, including time management, effort and persistence management, metacognition, and goal setting. Third, motivation and metacognitive processes play an important role in initiating, monitoring, and sustaining self-regulated learning, but their contribution to learning achievement is manifested through action and persistence [52], [53]. In an effort to achieve academic achievement during online learning, both teachers and students need to adapt their teaching and learning. Various forms of monitoring, regulation and assessment may have to be considered that reshape learner motivation, where students experience less didactic teaching and are expected to be less dependent on teachers so that ultimately requires students to equip themselves with the various skills needed to become more independent, effective and responsible answer [52].

\section{Research Question}

The overall research question is whether achievement motivation and SRL have a significant effect on learning behavior? The derived research questions are first, does Achievement Motivation have a significant positive effect on Learning Behavior? Second, does SRL have a significant positive effect on Learning Behavior?

\section{Results}

The validity test was carried out by correlating the answer scores of each question item with the number of variable scores. The correlation technique used is the Pearson product moment correlation technique according to the ordinal data measurement scale. The number used as a comparison to see whether an item is valid or not is 0.138 (the $r$ table value is more than 200 samples). While the reliability test is used to see the stability or consistency of the measurement results, the reliability technique used is consistency reliability between items using the Cronbach alpha test.

The results of the validity test on the Achievement Motivation research questionnaire compare the item correlation number with the total correlation obtained with the $r$ item number $>$ $r$ table [54]. Because the correlation number obtained from the questions on the $\times 1.1-\times 1.12$ indicators is above 0.138 , which ranges from 0.376 to 0.888 and thus the questions are decided to be significant and have good validity.

The reliability test in this study is using the Cronbach Alpha method. A construct or variable is said to be reliable if it gives a Cronbach alpha value > 0.60 [54]. Based on the calculation of the reliability test that has 
been carried out, it is found that the Achievement Motivation variable has a Cronbach alpha value above 0.6 , which is 0.847 so that this instrument belongs to a reliable and consistent instrument.

The results of the validity test in this research questionnaire compare the item correlation number with the total correlation obtained with the $r$ item number $>r$ table [54]. The results of the correlation number obtained from questions on the SRL (X2) variable indicator X2.1-X2.8 based on the output of IBM SPSS 22.0, are above 0.138 , which ranges from 0.285 to 0.658 , then the questions are decided significant and have good validity. Meanwhile, based on the calculation of the reliability test, it was obtained that the SRL variable had a Cronbach alpha value above 0.6 , which was 0.701 . This means that the instrument has reliable results, so this instrument or questionnaire is included as a reliable and consistent instrument.

The results of the validity test of the Learning Behavior variable based on the output of IBM SPSS 25.0 show that the correlation number obtained from the questions on the $Y 1-Y 10$ indicators is above 0.138 , which is ranging from 0.585 to 0.747 , thus the questions are decided to be significant and have good validity. Meanwhile, based on the calculation of the reliability test, it was found that the Learning Behavior variable has a Cronbach alpha value above 0.6 , which is 0.874 , this means that the instrument has reliable results, thus including the reliable and consistent instrument.

\section{Inferential Analysis}

The inferential analysis method used in this study is path regression analysis which is used to find the effect of independent variables on the dependent either directly or indirectly. Before conducting the path analysis, the classical assumption test will first be calculated with the aim that the resulting equation is a good and unbiazed equation. The classical assumption test used is the normality test, multicollinearity test, and heteroscedasticity test as follows.

Normality test to test whether in a regression model, the dependent variable, the independent variable, or both have a normal distribution or not. A good regression model is to have a normal distribution or close to normal. To detect whether the regression model is normally distributed or not, the KolmogorovSmirnov test is used, provided that the data are normally distributed if the sig value is above 0.05 . The results of the normality test can be seen from the Table 1 .

Based on the results of the data normality test, it was found that the sig value was above 0.05 , which was 0.200 , so it can be said that the regression model had a normal distribution.
Table 1: Data normality test

\begin{tabular}{ll}
\hline One-Sample Kolmogorov-Smirnov test & \\
\hline & Unstandardized Residual \\
\hline $\mathrm{N}$ & 2880 \\
Normal Parameters ${ }^{\mathrm{a}, \mathrm{b}}$ & \\
$\mathrm{Mean}$ & 0.0000000 \\
$\mathrm{SD}$ & 3.58666903 \\
Most extreme differences & 0.032 \\
Absolute & 0.032 \\
Positive & -0.023 \\
$\quad$ Negative & 0.032 \\
Test statistic & $0.200^{\mathrm{c}}$ \\
Asymp. Sig. (2-tailed) &
\end{tabular}

Multicollinearity testing aims to test whether the regression model found a correlation between independent variables. A good regression model should not have a correlation between independent variables. A good regression model should not have a correlation between the independent variables. If in the regression model that is formed there is a high or perfect correlation between the independent variables, then the regression model is declared to contain multicollinear symptoms. The multicollinearity test using tolerance (TOL) and statistical variance inflation factor (VIF) multicollinearity test by looking at the TOL andVIF of each independent variable on the dependent variable. If the VIF value is not more than 10 , then the model is declared to have no symptoms of multicollinearity. For the results of multicollinearity testing, it can be seen from the following table.

In the Table 2, it can be seen that the TOL value is above 0.10 and the VIF value is below 10 , so it can be concluded that there is no multicollinearity problem in the regression model.

Table 2: Multicollinearity test

\begin{tabular}{llll}
\hline Coefficients $^{\text {a }}$ & & \\
\hline Model & & Collinearity Statistics \\
\cline { 2 - 4 } & Achievement Motivation & 0.813 & VIF \\
\hline 1 & Self-Regulated Learning & 0.813 & 1.229 \\
& ${ }^{a}$ Dependent Variable: Learning Behavior. VIF: Variance inflation factor & 1.229 \\
\hline
\end{tabular}

Heteroscedasticity test aims to test whether in the regression model there is an inequality of variance from the residuals of one observation to another observation. If the variance of the residuals from one observation to another observation remains, it is called homoscedasticity, whereas if it is different it is called heteroscedasticity. A good regression model does not have heteroscedasticity problems. One way to find out whether there is heteroscedasticity in a multiple linear regression model is to look at the scatterplot graph or the predicted value of the dependent variable, namely SRESID with a residual error of ZPRED. If there is no certain pattern and it does not spread above and below zero on the $y$-axis, then there is no heteroscedasticity. A good model is one that does not occur heteroscedasticity [54]. The results of the heteroscedasticity test are as follows (Figure 1).

Based on the results of heteroscedasticity testing using a scatter plot, it can be seen that the value of the points is above and below zero, so it can be concluded that there is no heteroscedasticity problem in the research 


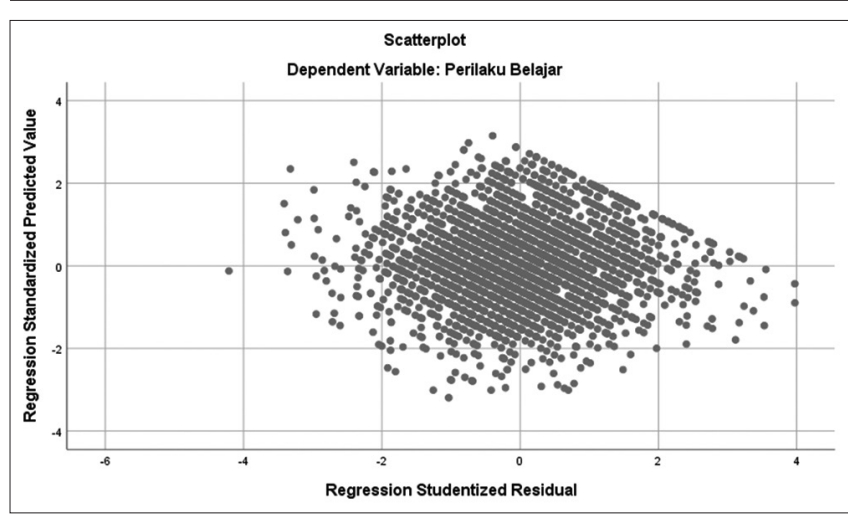

Figure 1: Picture of heteroscedasticity test

model. Thus, all classical assumption tests have been met so that the analysis can be continued because it has been found that there is no violation of classical assumptions.

\section{Correlation between Variables}

Pearson correlation coefficient is used to determine the close relationship of the variables of Achievement Motivation, SRL, and Student Learning Behavior. The following Table 3 is the result of calculating the correlation coefficient based on SPSS output.

Table 3: Correlation analysis results

\begin{tabular}{llll}
\hline Correlations & Achievement Motivation & SRL & Learning Behavior \\
\hline & & & \\
Achievement Motivation & 1 & 0.432 & 0.632 \\
Pearson Correlation & & 0.000 & 0.000 \\
Sig. (2-tailed) & 2880 & 2880 \\
N & & \\
SRL & 1 & 0.675 \\
Pearson Correlation & & 0.000 \\
Sig. (2-tailed) & & 2880 \\
N & & & \\
\hline
\end{tabular}

Based on the calculation results, it can be seen that the correlation coefficient of Achievement Motivation with SRL is 0.432 with a significant relationship because it has a significance value $<0.05$. The correlation coefficient of 0.432 is included in the category of a fairly strong relationship, meaning that there is a fairly strong relationship between Achievement Motivation and SRL. The correlation coefficient between Achievement Motivation and Learning Behavior is 0.632 with a significant relationship because it has a significance value less than 0.05 . The correlation coefficient of 0.632 is included in the category of a strong relationship, meaning that there is a strong relationship between Achievement Motivation and Learning Behavior. The correlation coefficient between SRL and Learning Behavior is 0.675 with a significant relationship because it has a significance value $<0.05$. The correlation coefficient of 0.675 is included in the category of a strong relationship, meaning that there is a strong relationship between SRL and Learning Behavior.

\section{Path Analysis}

Furthermore, according to the research objectives, namely to examine the effect of Achievement Motivation (X1) and SRL (X2) on Learning Behavior (Y). This data processing uses path analysis. In accordance with the proposed research hypothesis, the data will be tested using path analysis. Path analysis examines the structural causal relationship of the independent variable to the dependent variable by considering the relationship between the independent variables. Based on the results of data processing, the path coefficients of each independent variable are obtained, namely, Achievement Motivation (X1) and SRL (X2) on Learning Behavior $(Y)$ as shown in the Table 4.

Table 4: Path analysis calculation results

\begin{tabular}{|c|c|c|c|c|c|c|}
\hline \multicolumn{7}{|c|}{ Coefficients $^{a}$} \\
\hline \multirow{3}{*}{\multicolumn{2}{|c|}{ Mode }} & \multirow{2}{*}{\multicolumn{2}{|c|}{$\begin{array}{l}\text { Unstandardized } \\
\text { Coefficients }\end{array}$}} & \multirow{3}{*}{$\begin{array}{l}\text { Standardized } \\
\text { Coefficients } \\
\text { Beta }\end{array}$} & \multirow[t]{3}{*}{$\mathrm{t}$} & \multirow[t]{3}{*}{ Sig. } \\
\hline & & & & & & \\
\hline & & $B$ & Std. Error & & & \\
\hline \multirow[t]{3}{*}{1} & (Constant) & -1.965 & 0.461 & & -4.265 & 0.000 \\
\hline & Achievement Motivation & 0.401 & 0.013 & 0.418 & 31.881 & 0.000 \\
\hline & Self-Regulated Learning & 0.754 & 0.020 & 0.494 & 37.692 & 0.000 \\
\hline
\end{tabular}

Based on the Path Analysis Calculation Result Table, the path coefficient value for Achievement Motivation is 0.418 with a positive relationship direction. This indicates that when achievement motivation increases by one percent, it will cause learning behavior to increase by $0.418 \%$. Then, the path coefficient value for SRL is 0.494 with a positive relationship direction. That is, when SRL increases by one percent, it will cause learning behavior to increase by $0.494 \%$. Based on the results of these calculations, the path analysis model equation can be made as follows.

$$
\mathrm{Y}=0.418 \mathrm{X} 1+0.494 \mathrm{X} 2+\mathrm{e}
$$

After the path coefficient is calculated, then to prove whether Achievement Motivation (X1) and SRL (X2) have a significant effect either partially or simultaneously on Learning Behavior ( $\mathrm{Y}$ ), then hypothesis testing is carried out. Hypothesis testing starts with simultaneous testing and then continues with partial tests.

\section{Simultaneous Hypothesis Testing}

Simultaneous testing is carried out to prove whether Achievement Motivation and SRL together have an effect on Learning Behavior.

\section{Hypothesis 1 \\ $\mathrm{H}_{01}$ : Achievement Motivation and SRL have no significant effect on Learning Behavior. \\ $\mathrm{H}_{\mathrm{a} 1}$ : Achievement Motivation and SRL have a significant effect on Learning Behavior.}


The hypothesis testing is carried out through the $\mathrm{F}$ test statistic with the following conditions:

Reject $\mathrm{H}_{0}$ if $\mathrm{F}_{\text {count }}$ is greater than $\mathrm{F}_{\text {table }}\left(\mathrm{F}_{\text {count }}>\mathrm{F}_{\text {table }}\right)$ Accept $\mathrm{H}_{0}$ if $\mathrm{F}_{\text {count }}$ is less than or equal to $\mathrm{F}_{\text {table }}$ $\left(\mathrm{F}_{\text {count }} \leq \mathrm{F}_{\text {table }}\right)$

And the SPSS calculation results are obtained as below Table 5:

Table 5: Simultaneous hypothesis testing

\begin{tabular}{|c|c|c|c|c|c|c|}
\hline \multicolumn{7}{|c|}{$\overline{\text { ANOVA }^{a}}$} \\
\hline & & Sum of Squares & df & Mean Square & $\mathrm{F}$ & Sig. \\
\hline \multirow[t]{3}{*}{ 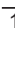 } & Regression & 54991.671 & 2 & 27495.835 & 2135.908 & $0.000^{6}$ \\
\hline & Residual & 37036.017 & 2877 & 12.873 & & \\
\hline & Total & 92027.687 & 2879 & & & \\
\hline
\end{tabular}

\section{Sumber: Hasil Olah Data SPSS, 2021}

With a value of $=5 \%$; $\quad \mathrm{df} 1=\mathrm{k}=2$; $\mathrm{df} 2=\mathrm{n}-\mathrm{k}-1=2880-2-1=2877$ the $\mathrm{F}_{\text {table }}$ value is 2.999 . Based on the results of the calculation of $F_{\text {count }}$ obtained by 2135.9 with a $f_{\text {alue of } 2.999}$. The test criteria are, "reject $\mathrm{H}_{\mathrm{o}}$ if $\mathrm{F}_{\text {count }}>\mathrm{F}_{\text {table. }}$ "Because from the test results obtained the value of $F_{\text {count }}=2135.9>F_{\text {table }}=2.999$, then at $=5 \%$ it was decided to reject $\mathrm{H}_{01}$ so that $\mathrm{H}_{\mathrm{a} 1}$ is accepted, meaning that Achievement Motivation and SRL have a significant effect on Learning Behavior.

\section{Partial Hypothesis Testing}

Partial testing was conducted to prove whether achievement motivation (X1) and SRL (X2) had a significant effect on Learning Behavior ( $Y$ ). To test the path coefficients of each independent variable, a statistical $t$ test was used by looking at the magnitude of the $p$-value (sig) compared to 0.05 (significance level = 5\%).

Testing the Effect of Achievement Motivation (X1) on Learning Behavior (Y)

Analysis of the influence of Achievement Motivation variable (X1) on Learning Behavior (Y) obtained results based on the results of calculations with SPSS software as follows:

Based on the Table 6 Effects of Achievement Motivation (X1) on Learning Behavior ( $Y$ ), it can be seen that the direction of the relationship between Achievement Motivation (X1) and Learning Behavior $(\mathrm{Y})$ is positive where it is written 0.418 meaning that when there is an increase in Achievement Motivation (X1) it will increase Learning Behavior (Y) and vice versa. Then, the author tested the hypothesis using the t-test by looking at the magnitude of the p-value (sig) compared to 0.05 (significance level $=5 \%$ ). The test criteria used were:

Table 6: Effects of achievement motivation (X1) on learning behavior (Y)

\begin{tabular}{lllll}
\hline & Beta & $\mathrm{t}_{\text {count }}$ & $\mathrm{p}$ value & Label \\
\hline $\begin{array}{l}\text { Achievement Motivation } \rightarrow \text { Learning } \\
\text { Behavior }\end{array}$ & 0.418 & 31.881 & 0.000 & Significant \\
\hline
\end{tabular}

If $\mathrm{p}>0.05$ then $\mathrm{H}_{0}$ is accepted.

If $p<0.05$ then $\mathrm{H}_{0}$ is rejected.

\section{Hypothesis 2}

$\mathrm{H}_{02}$ : There is no positive and significant effect of Achievement Motivation on Learning Behavior.

$\mathrm{H}_{\mathrm{a} 2}$ : There is a positive and significant influence of Achievement Motivation on Learning Behavior.

Based on the provisions that have been stated previously, which obtained a p-value of 0.000 so that the $\mathrm{p} \leq 0.05$. This means that $\mathrm{H}_{01}$ is rejected and $\mathrm{Ha} 1$ is accepted, then there is a positive and significant influence between Achievement Motivation on Learning Behavior. Thus, the hypothesis which states that there is a positive influence between Achievement Motivation on Learning Behavior is acceptable. Behavior (Y)

Testing the Effect of SRL (X2) on Learning

Analysis of the influence of the variable SRL (X2) on Learning Behavior (Y) obtained results based on the results of calculations with SPSS software as follows:

Based on the Table 7 Effects of SRL (X3) on Learning Behavior $(Y)$, it can be seen that the direction of the relationship of SRL (X2) on Learning Behavior (Y) is positive where it is written 0.494 meaning that when there is an increase in SRL (X2) it will increase Learning Behavior (Y).

Table 7: Effects of SRL (X3) on learning behavior (Y)

\begin{tabular}{lllll}
\hline & Beta & $\mathrm{t}_{\text {count }}$ & $\mathrm{p}$ & Label \\
\hline $\mathrm{SRL} \rightarrow$ Learning Behavior & 0.494 & 37.692 & 0.000 & Significant \\
\hline SRL: Self-regulated learning & & & &
\end{tabular}

\section{Hypothesis 3}

$\mathrm{H}_{03}$ : There is no positive and significant effect of SRL on Learning Behavior.

$\mathrm{H}_{\mathrm{a} 3}$ : There is a positive and significant effect of SRL on Learning Behavior.

Based on the provisions that have been stated previously, which obtained a p-value of 0.000 so that the $p \leq 0.05$. This means that $\mathrm{H}_{03}$ is rejected and $\mathrm{H}_{\mathrm{a}}$ is accepted, then there is a positive and significant influence between SRL on Learning Behavior. Thus, the hypothesis which states that there is a positive influence between SRL on Learning Behavior can be accepted.

So based on the test results, it can be concluded that Achievement Motivation and SRL have a significant effect on Learning Behavior. The picture of the path analysis model for the research is as follows (Figure 2).

The coefficient of determination is used to The coefficient of determination is used to see the magnitude 


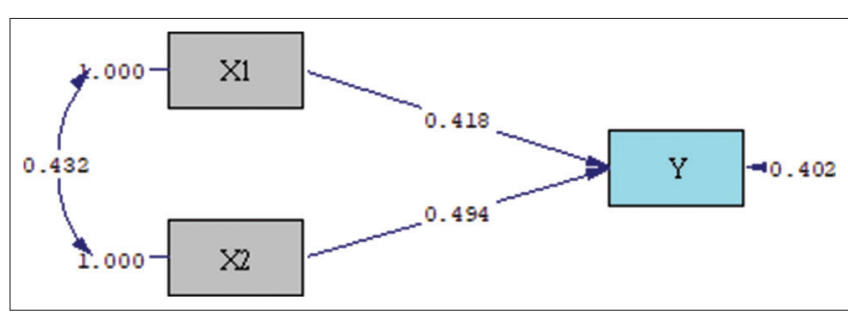

Figure 2: Coefficient of determination (R2)

of the influence of Achievement Motivation and SRL on Learning Behavior. The following are the results of the calculation of the coefficient of determination based on the SPSS output.

Based on the Table 8 Coefficient of Determination (R2), it can be seen that the value of the simultaneous correlation coefficient is 0.773 , then the coefficient of determination (R2) is 0.598 . This means that there is an influence between the variables of Achievement Motivation and SRL on Learning Behavior of $59.8 \%$, while the remaining $40.2 \%$ is the influence of other variables that the researcher did not involve in this study (Table 9). Then to answer the problem formulation regarding the magnitude of the influence of Achievement Motivation and SRL on Behavior, either directly or indirectly, the calculation of the magnitude of the partial influence is carried out as follows.

The direct influence of Achievement Motivation on Learning Behavior is $17.5 \%$ and the indirect effect through SRL is $8.9 \%$, so that if added up, the total effect is $26.4 \%$. Then, the direct effect of SRL on Learning Behavior is $24.4 \%$ and the indirect effect through Achievement Motivation is $8.9 \%$, so that if added up, the total effect is $33.4 \%$.

Based on the description above, it can be concluded that the hypothesis test is described as follows:

$\mathrm{H}_{1}$ : The first hypothesis can be accepted because there is a significant influence between Achievement Motivation and SRL on Student Learning Behavior simultaneously.

$\mathrm{H}_{2}$ : The second hypothesis can be accepted because there is a significant influence between Achievement Motivation on Student Learning Behavior partially.

$\mathrm{H}_{3}$ : The third hypothesis can be accepted because there is a significant influence between SRL on Student Learning Behavior partially.

\section{Discussion}

\section{The relationship between achievement motivation and learning behavior}

The results showed that based on the provisions that have been stated previously, which obtained a $p$ value of 0.000 so that the $p \leq 0.05$. This means that $\mathrm{H}_{01}$ is rejected and $\mathrm{H}_{\mathrm{a} 1}$ is accepted, then there is a positive and significant influence between Achievement Motivation on Learning Behavior. Thus, the hypothesis which states that there is a positive influence between Achievement Motivation on Learning Behavior is acceptable. The results of this study are in line with Fatchurrohman's [55] research which says that between the relationship between increasing achievement motivation and increasing student learning readiness, the results are in the form of a positive relationship through the correlation coefficient test of 0.786 and seen from the determination test of achievement motivation, it contributes $61.79 \%$. Another study belonging to Trisnowali [56] said that the results of the analysis with SPSS showed that if the p-value was $0.00<0.05$ which means significant, it means that $\mathrm{H}_{0}$ is rejected so that $\mathrm{H}_{1}$ which states that achievement motivation, attitude to learning mathematics and interest in learning mathematics together - Equally positive with the mathematics learning outcomes of class $X$ students of SMA Negeri 2 Watampone.

The results of another study Dwija [57] identified data that showed that the results between achievement motivation and sociology learning outcomes had a strong correlational relationship, this is indicated by the regression equation $=7.145+0.344 \times 2$ with $a$ correlation coefficient of $r=0.415$ and is significant at level 0.05 or 0.01 with the achievement of learning outcomes in sociology of $17.2 \%$. Research conducted there is a high influence between student study habits and learning motivation as evidenced by a correlation coefficient of 0.77 and a determination of $59 \%$ and it is also explained that an increase or decrease in student achievement motivation is influenced by a study habit as much as $59 \%$ while the rest is influenced by the presence of other factors as much as $41 \%$ [58].

Research on study habits has also been investigated [59]. The results show that there is an influence of achievement motivation on integrated social studies learning outcomes for class VIII students and there is also an influence between study habits and achievement motivation on social studies learning outcomes with a value of $27.8 \%$. Groups of students who have high achievement motivation will get learning

Table 8: Coefficient of determination (R2)

\begin{tabular}{|c|c|c|c|c|c|c|c|c|c|}
\hline \multicolumn{10}{|c|}{ Model Summary } \\
\hline \multirow{2}{*}{ Model } & \multirow[t]{2}{*}{$\mathrm{R}$} & \multirow[t]{2}{*}{ R Square } & \multirow[t]{2}{*}{ Adjusted R Square } & \multirow[t]{2}{*}{ Std. Error of the Estimate } & \multicolumn{5}{|l|}{ Change Statistics } \\
\hline & & & & & R Square Change & F Change & df1 & df2 & Sig. F Change \\
\hline 1 & $0.773^{\mathrm{a}}$ & 0.598 & 0.597 & 3.58792 & 0.598 & 2135.908 & 2 & 2877 & 0.000 \\
\hline
\end{tabular}


Table 9: Partial effects

\begin{tabular}{|c|c|c|c|c|c|c|}
\hline \multirow[t]{2}{*}{ Variable } & \multirow[t]{2}{*}{ Coefficient path } & \multirow[t]{2}{*}{ Direct Influence } & \multicolumn{2}{|c|}{ Indirect Influence } & \multirow[t]{2}{*}{ Total Influence } & \multirow[t]{2}{*}{$\%$} \\
\hline & & & Through $X_{1}$ & Through $\mathrm{X}_{2}$ & & \\
\hline Achievement Motivation & 0.418 & 0.175 & & 0.089 & 0.264 & $26.4 \%$ \\
\hline Self-Regulated Learning & 0.494 & 0.244 & 0.089 & & 0.334 & $33.4 \%$ \\
\hline Total Influence & & & & & 0.598 & $59.8 \%$ \\
\hline
\end{tabular}

outcomes with better understanding and application of concepts, students with high achievement motivation will always be tough, work hard, want to get higher grades, not easily discouraged, oriented to the future, worry about failure, likes quick feedback about their achievements, enjoys difficult tasks and is responsible for solving a problem [60].

\section{behavior}

The relationship between SRL and learning

Based on the provisions that have been stated previously, which obtained a p-value of 0.000 so that the $p \leq 0.05$. This means that $\mathrm{H}_{03}$ is rejected and $\mathrm{H}_{\mathrm{a}}$ is accepted, then there is a positive and significant influence between SRL on Learning Behavior. Thus, the hypothesis which states that there is a positive influence between SRL on Learning Behavior can be accepted. The results of this study are in line with the research conducted by Susilo [61] which states that the results using a descriptive analysis of Pearson's parametric correlation obtained the results of Pearson's $r_{x y}=0.586^{* *}$ with a significant value $=0.000(p<0.05)$ which means that there is a relationship a very significant positive relationship between learning motivation and $\mathrm{SRL}$ in high school students. Another study belonging to Hasnah [62] said that research conducted using the product moment coefficient $r_{x y}=0.480 ; p=0.000$ means $p<0.050$, which means that there is a positive relationship between learning motivation and SRL in other words that SRL is influenced by learning motivation with a percentage of $23.0 \%$.

SRL has an effect on students' problem-solving abilities [63] shows that there is a relationship between students' SRL and students' mathematical solving abilities. A SRL strategy in which there are several stages, including the preparation stage where to set plans and goals, the implementation stage where at this stage students carry out a control over themselves by giving instructions to focus attention on the process that is being undertaken besides that students also make personal experiments through the material. and tasks that already exist, and then the reflection stage where at this stage is the last stage where students look back at their performance and determine the feelings they feel and the influence they will have on their performance [64].

The face-to-face learning system that turns into online learning during the COVID-19 pandemic certainly has an impact on changes to the learning process and pattern of a student, therefore the need for SRL capabilities that must be possessed in carrying out the online learning process at home. During the
COVID-19 pandemic [65], creating a learning skill and independence in the midst of the COVID-19 pandemic is the most important thing [66].

\section{Conclusion}

There is a significant effect between achievement motivation and SRL on student learning behavior simultaneously; there is a significant influence between achievement motivations on student learning behavior partially. There is a significant influence between SRL on Student Learning Behavior partially.

\section{References}

1. Harapan $\mathrm{H}$, Itoh $\mathrm{N}$, Yufika $\mathrm{A}$, Winardi $\mathrm{W}$, Keam $\mathrm{S}, \mathrm{Te} \mathrm{H}$ et al. Coronavirus disease 2019 (COVID-19): A literature review. J Infect Public Health. 2020;13(5):667-73. https://doi. org/10.1016/j.jph.2020.03.019

PMid:32340833

2. Johnson M. Wuhan 2019 novel coronavirus 2019-nCoV. Mater Methods. 2020;10:1-5.

3. Levani $Y$, Prastya AD, Mawaddatunnadila S. Coronavirus disease 2019 (COVID-19): patogenesis, manifestasi klinis dan pilihan terapi. J Kedokt Kesehat. 2021;17(1):44-57.

4. Nursofwa RF, Sukur MH, Kurniadi BK, Haris. Penanganan pelayanan kesehatan $\mathrm{Di}$ masa pandemi Covid-19 dalam perspektif hukum kesehatan. Inicio Legis. 2020;1(1):1-17.

5. Wu YC, Chen CS, Chan YJ. The outbreak of COVID-19. J Chinese Med Assoc. 2020;83(3):217-20. https://doi. org/10.1097/JCMA.0000000000000270 PMid:32134861

6. Yuliana Y. Corona virus diseases (Covid-19): Sebuah tinjauan literatur. Wellness Heal Mag. 2020;2(1):187-92.

7. Crawford J, Henderson KB, Rudolph J, Malkawi B, Glowatz M, Burton R, et al. COVID-19: 20 countries' higher education intra-period digital pedagogy responses. J Appl Learn Teach. 2020;3(1):1-20. https://doi.org/10.37074/jalt.2020.3.1.7

8. Cahyani A, Listiana ID, Larasati SP. Motivasi belajar siswa SMA pada pembelajaran daring di masa pandemi Covid-19. IQ (IImu Al-qur'an). J Pendidik Islam. 2020;3(1):123-40.

9. Hafida H, Wilanika W, Sapta S. Penurunan motivasi dan keaktifan belajar siswa selama pembelajaran daring di tengah pendemi Covid-19. Indones J Educ Sci. 2020;2(2):82.

10. Izzatunnisa L, Suryanda A, Kholifah AS, Loka C, Goesvita PP, Aghata PS, et al. Motivasi belajar siswa selama pandemi dalam proses belajar dari rumah. J Pendidikan. 2019;1(2):105-12.

11. Nurfaisal $N$. Motivasi belajar siswa selama pandemi COVID-19 dalam poses belajar dari rumah. J. IImiah MEA. 
2021;5(1):1800-8.

12. Safarati RN. Dampak pembelajaran daring terhadap motivasi. Genta Mulia. 2021;12(1):113-8.

13. Pintrich PR. The role of goal orientation in self-regulated learning. In: Handbook Self-Regulation. 2000. p. 451-502.

14. Casillas A, Robbins $S$, Allen J, Kuo YL, Hanson MA, Schmeiser C. Predicting early academic failure in high school from prior academic achievement, psychosocial characteristics, and behavior. J Educ Psychol. 2012;104(2):407-20.

15. Lucio R, Hunt E, Bornovalova M. Identifying the necessary and sufficient number of risk factors for predicting academic failure. Dev Psychol. 2012;48(2):422-8. https://doi.org/10.1037/ a0025939

PMid:22182300

16. Ohrt J. The effects of A suiccess skills group on adolescents' selfregulation, self-esteem, and perceived learning competence. ASCA. 2010;18(1):169-78.

17. American School Counselor Association. Position Statement: The Proffesional School Counsellor and the Identification, Prevention, and Intervention of Behaviors that are Harmful and Place Students at Risk; 2011. Available from: http://www. schoolcounselor.org/asca/media/asca/positionstatements/ps_ atris [Last accessed on 2021 Nov 01].

18. Tao VY, Hong Y. When academic achievement is an obligation: Perspectives from social-oriented achievement motivation. J Cross Cult Psychol. 2014;45(1):110-36.

19. Dörnyei Z. Individual Differences in Second Language Acquisition; 2006. p. 42-68.

20. Schunk DH, Zimmerman BJ. Motivation and Self-regulated Learning: Theory, Research and Application. $3^{\text {rd }}$ ed. Milton Park, Abingdon-on-Thames: Routledge; 2008.

21. Teng LS. Individual differences in self-regulated learning: Exploring the nexus of motivational beliefs, self-efficacy, and SRL strategies in EFL writing. Lang Teach Res. 2021:1-23. Doi: $10.1177 / 13621688211006881$

22. Salsabila S, Savira I. Motivasi Berprestasi Akademik Siswa sd Selama Pembelajaran Daring (Studi Kasus Pada Anggota Al-akbar Student Council) Safira Salsabila Siti Ina Savira; 2021.

23. Bandura A. Self-efficacy: The Exercise of Control. New York: W.H Freeman; 1997.

24. Elliot AJ, McGregor HA. A $2 \times 2$ achievement goal framework. J Pers Soc Psychol. 2001;80(3):501-19. https://doi. org/10.1037/0022-3514.80.3.501

PMid:11300582

25. Zimmerman BJ. Attening self-regulation A social cognitive perspective. In: Handbook of Self-Regulation. Ch. 2. Cambridge, Massachusetts: Academic Press; 2000. p. 13-39.

26. Chan JC, Lam SF. Effects of competition on students self-efficacy in vicarious learning. $\mathrm{Br} J$ Educ Psychol. 2008;78(1):95-108. https://doi.org/10.1348/000709907X185509 PMid: 17535508

27. Zimmerman BJ. Becoming a self-regulated learner: Which are the key subprocesses? Contemp Educ Psychol. 1986;11(4):307-13.

28. Zimmerman BJ, Pons MM. Development of a structured interview for assessing student use of self-regulated learning strategies. Am Educ Res J. 1986;23(4):614-28.

29. Zimmerman BJ. Investigating self-regulation and motivation: Historical background, methodological developments, and future prospects. Am Educ Res J. 2008;45(1):166-83.

30. Zimmerman BJ. Becoming a self-regulated learner: An overview. Theory Pract. 2010;5841(1):64-70.

31. Usher EL, Pajares F. Self-efficacy for self-regulated learning: A validation study. Educ Psychol Meas. 2008;68(3):443-63.

32. Zimmerman BJ. From cognitive modeling to self-regulation: A social cognitive career path. Educ Psychol. 2013;48(3):135-47. https://doi.org/10.1080/00461520.2013.794676

33. Teng LS, Zhang LJ. A questionnaire-based validation of multidimensional models of self-regulated learning strategies. Mod Lang J. 2016;100(3):674-701. https://doi.org/10.1111/modl.12339

34. Oxford RL. Teaching and Researching language Learning Strategies. $1^{\text {st }}$ ed. Milton Park, Abingdon-on-Thames: Routledge; 2017

35. Pajares F. Motivational role of self-efficacy beliefs in selfregulated learning. In: Schunk $\mathrm{DH}$, Zimmerman BJ, editors. Motivation and Self-regulated Learning: Theory, Research, and Applications. Mahwah: Lawrence Erlbaum Associates Publishers; 2008. p. 111-39.

36. Pintrich P, Smith D, Garcia T, McKeachie W. A Manual for the Use of the Motivated Strategies for Learning Qustionnaire (MSLQ). Ann Arbor, MI: University of Michigan; 1991.

37. Duncan TG, McKeachie WJ. The making of the motivated strategies for learning questionnaire. Educ Psychol. 2005;40(2):117-28. https://doi.org/10.1207/s15326985ep4002_6

38. Bai B, Wang J. Hong Kong secondary students' self-regulated learning strategy use and English writing: Influences of motivational beliefs. System. 2021;96:102404. https://doi. org/10.1016/j.system.2020.102404

39. Pintrich PR, De Groot EV. Motivational and self-regulated learning components of classroom. J Educ Psychol. 1990;82(1):33-40.

40. Lyke JA, Young AJ. Cognition in context: Students' perceptions of classroom goal structures and reported cognitive strategy use in the college classroom. Res High Educ. 2006;47(4):477-90.

41. Pintrich PR. A conceptual framework for assessing motivation and SRL in college students. Educ Psychol Rev. 2004;16(4):385-407.

42. Zimmerman BJ, Schunk DH. Self-regulated learning and performance: An introduction and an overview. In: Zimmerman BJ, Schunk DH, editors. Handbook of Selfregulation of Learning and Performance. New York: Roultledge; 2011. p. 1-12.

43. Bai B, Wang J. The role of growth mindset, self-efficacy and intrinsic value in self-regulated learning and English language learning achievements. Lang Teach Res. 2020. https://doi. org/10.1016/j.system.2020.102404

44. Rosenthal H, Wolters CA. The relation between students motivational beliefs and their use of motivational regulation strategies. Int J Educ Res. 2000;33:801-20. https://doi. org/10.1016/S0883-0355(00)00051-3

45. Robbins SB, Oh IS, Le H, Button $\mathrm{C}$. Intervention effects on college performance and retention as mediated by motivational, emotional, and social control factors: Integrated meta-analytic path analyses. J Appl Psychol. 2009;94(5):1163-84. https://doi. org/10.1037/a0015738 PMid:19702363

46. Zimmerman BJ, Schunk DH. Self-regulated Learning and Academic Achievment: Theory, Research, and Practice. Berlin, Heidelberg: Springer-Verlag Pblishing; 1989.

47. Zimmerman BJ. Self-regulated learning and academic achievement: An overview. Educ Psychol. 1990;25(1):3-17.

48. Miller DC, Byrnes JP. To archieve or not archieve: A selfregulation perspective on adolescents's academic decision making. J Educ Psychol 2001;93(4):677-85.

49. Reid R, Trout AL, Schartz M. Self-regulation interventions for children with attention deficit/hyperactivity disorder. Exceptional Children 2005;71:361-77.

50. Zimmerman BJ. Self-Regulated Learning: Theories, Measures, and Outcomes $2^{\text {nd }}$ ed., Vol. 21. Amsterdam, Netherlands: International Encyclopedia of the Social and Behavioral Sciences, Elsevier; 2015. p. 541-6.

51. Madjar N, Weinstock M, Kaplan A. Epistemic beliefs and 
achievement goal orientations: Relations between constructs versus personal profiles. J Educ Res. 2017;110(1):32-49. http:// dx.doi.org/10.1080/00220671.2015.1034353

52. Rivers DJ, Nakamura M, Vallance M. Online self-regulated learning and achievement in the era of change. J Educ Comput Res. 2021:1-28. Doi: 10.1177/07356331211025108.

53. Dent AL, Koenka AC. The relation between self-regulated learning and academic achievement across childhood and adolescence: A meta-analysis. Educ Psychol Rev. 2016;28(3):425-74.

54. Ghozali I. Aplikasi Analisis Multivariate dengan Program IBM SPSS 21 update PLS Regresi. Semarang: Badan Penerbit Universitas Diponegoro; 2013.

55. Fatchurrohman R. Pengaruh motivasi berprestasi terhadap kesiapan belajar, pelaksanaan prakerin dan pencapaian kompetensi mata pelajaran produktif. Innov Vocat Technol Educ. 2017;7(2):164-74.

56. Trisnowali A. Pengaruh motivasi berprestasi, minat belajar matematika, dan sikap belajar matematika terhadap hasil belajar matematika pada siswa sman 2 watampone. MaPan. 2017;5(2):259-78.

57. Dwija IW. Hubungan antara konsep diri, motivasi berprestasi dan perhatian orang tua dengan hasil belajar sosiologi pada siswa kelas ii sekolah menengah atas unggulan di kota amlapura. J Pendidik Pengajaran. 2008;1:628-49.

58. Sundari FS, Kurnia D, Sukmanasa E, Novita L. Pengaruh kebiasaan belajar siswa sd terhadap motivasi berprestasi.
Indones J Prim Educ. 2021;5(1):1-12.

59. Anggareni NW, Ristiati NP, Widiyanti NL. implementasi strategi pembelajaran inkuiri terhadap kemampuan berpikir kritis dan pemahaman konsep IPA Siswa SMP. e-Journal Progr Pascasarj Univ Pendidik Ganesha. 2013;3:1-11.

60. Sumarno. Hubungan strategi umpan balik (feedback), motivasi berprestasi dan hasil belajar dalam pembelajaran PPKn di SMK. PINUS J Penelit Inov Pembelajaran. 2020;5(2):39-56.

61. Susilo R. Hubungan antara motivasi belajar dengan selfregulated learning pada siswa kelas $\mathrm{X}, \mathrm{XI}$, dan XII SMAN 6 tambun selatan. Sifonoforos. 2018;1(1):1-6.

62. Hasnah S. Learning Siswa Unggulan Di Sekolah Sekolah Menengah Kejuruan Negeri 2 Medan Fakultas Psikologi Medan; 2018.

63. Zamnah LN. Penggunaan squiggle-m dalam pembelajaran matematika untuk meningkatkan kemampuan pemahaman matematik. J THEOREMS. 2017;2(1):67-73.

64. Hudaifah F. Peran self regulated learning di era pandemi COVID-19. J Ilm Kegur Ilmu Pendidik. 2020;6(2):76-84.

65. Rizkyani AM, Feronika T, Saridewi N. Hubungan antara self regulated learning dengan prokrastinasi akademik pada mahasiswa pendidikan kimia di masa pandemi Covid-19. Edusains. 2020;12(2):252-8.

66. Herliandry LD, Nurhasanah $N$, Suban ME, Kuswanto $H$ Pembelajaran pada masa pandemi Covid-19. J Teknol Pendidik. 2020;22(1):65-70. 